\title{
MODEL DEMOKRASI DALAM PENINGKATAN KUALITAS PELAYANAN PUBLIK (Studi Otonomi Daerah dalam Peningkatan Kesejahteraan Masyarakat Pasca Reformasi)
}

\author{
Yusnani Hasjimzum \\ Fakultas Hukum Universitas Lampung \\ E-mail: yus_zoem@yahoo.com
}

\begin{abstract}
Quality improvement on public service has been regulated by various regulations. Until present, there are still many complaints due to poor service provided by government which does not meet people's expectation. Moreover, bureaucracy is still not effective to provide appropriate service to public resulting in a low quality service. To meet public's need, people are necessarily involved in as the implementation of democracy as the effort of establishing a democratic government.
\end{abstract}

Key words: democracy model, quality improvement, public service

\begin{abstract}
Abstrak
Peningkatan kualitas pelayanan publik telah banyak di atur diberbagai peraturan, hingga saat ini masih banyak keluhan, ketidakpuasan masyarakat, karena pelayanan yang diberikan pemerintah tidak sesuai dengan harapan, Birokrasi belum optimal memberikan pelayanan yang sesuai dan tepat kepada masyarakat sehingga kualitas pelayanan publik menjadi rendah. Untuk mendapatkan pelayanan yang sesuai dengan kebutuhan masyarakat, masyarakat harus dilibatkan dalam mengambil kebijakan melalui Partisipasi masyarakat yang merupakan dasar pelaksanaan demokrasi, guna mewujudkan pemerintahan yang demokratis
\end{abstract}

Kata kunci: model demokrasi, peningkatan kualitas, pelayanan publik .

\section{Pendahuluan}

Sejak reformasi dan diberlakukannya Undang-Undang Nomor 22 Tahun 1999 tentang Pemerintahan Daerah dan Undang-Undang Nomor 25 Tahun 1999 tentang Perimbangan Keuangan antara Pemerintah Pusat dan Daerah, terjadi perubahan dalam pelaksanaan sistem pemerintahan di daerah yang semula bersifat sentralistik dengan sistem top down begeser kepelaksanaan pemerintah daerah yang bersifat desentralistik. Secara formal pemerintah menyerahkan kewenangan kepada daerah otonom untuk mengurus rumah tangganya sendiri dan memenuhi kebutuhan yang sesuai dengan aspirasi masyarakatnya.

Penguatan otorisasi pemerintah daerah melalui kebijakan otonomi ini menghasilkan kemajuan dibidang demokrasi lokal dengan mene- rapkan sistem keterbukaan informasi dan pemberian pelayanan kepada masyarakat, sesuai dengan tujuan desentralisasi dan otonomi daerah adalah mendekatkan pemerintah kepada masyarakat yang dilayani sehingga pemerintah daerah dapat mengakomodir seluruh kebutuhan dan kepentingan masyarakatnya untuk mewujudkan masyarakat yang sejahtera.

Paradigma desentralisasi telah menumbuhkan kepekaan masyarakat untuk menuntut kualitas pelayanan publik (public service) yang merupakan kewajiban dari pemerintah daerah. Hasbullah Malau mengatakan, ${ }^{1}$ untuk meningkatkan pelayanan publik yang berkualitas dan bermutu, pemerintah daerah sebaiknya meru-

Hasbullah Malau, "Menyoal Pelayanan Publik yang Berkualitas di Era Otonomi Daerah", Jurnal Ilmiah Politik Kenegaraan, Vol. VIII No.1 Edisi Oktober 2009, Universitas Negeri Padang, hlm.14. 
bah paradigma berfikir dan bertindak yang ada di birokrasi daerah dari paradigma dilayani, pangreh praja, memerintah dan menguasai menjadi paradigma melayani, pelayan masyarakat, penyuguhi masyarakat, memfasilitasi dan mengajak masyarakat untuk berpartisipasi dalam pelayanan publik, memberikan pelayanan prima, responsif, transparan, akuntabel, komunikatif.

Berkaitan dengan hal tersebut, Karjuni Dt Maani mengemukakan, ${ }^{2}$ bahwa penyelenggara pelayanan publik harus bertanggungjawab dalam menjalankan wewenangnya dengan baik, karena publik memiliki hak untuk mengontrol, mempertanyakan dan meminta pertanggungjawaban aparat pemerintah (melalui wakilnya). Dengan akuntabilitas dan responsibilitas publik, setiap aparat pemerintah diminta untuk dapat mempertanggungjawabkan hak, kewajibannya, tindakannya, keahliannya bahkan waktu yang dipergunakan di depan publik, dengan sistem administrasi negara yang efisien dan efektif bukan berarti pengaduan publik di berbagai aspek pembangunan sudah meningkat kearah yang lebih baik, tetapi merupakan ciptaan kreatif dasar pengelolaan pemerintahan yang proaktif terhadap berbagai kebutuhan publik. Posisi aparatur pemerintah seharusnya mampu mendorong aktivitas publik.

Pendapat ini didukung $\mathrm{H}$. Alwi Wahyudi yang menyatakan, ${ }^{3}$ bahwa peran birokrasi tidak hanya mengandalkan kebutuhan barang dan jasa publik, melainkan sekaligus sebagai motivator tumbuh kembangnya peran serta masyarakat dalam pemenuhan kebutuhan masyarakat sendiri. Profesionalisme yang dikembangkan melalui kekuatan etika dan moralitas, penegakan supremasi hukum merupakan faktor utama untuk mewujudkan penyelenggaraan pelayanan publik yang memenuhi prinsip transparansi dan akuntabel, membawa pengaruh terhadap partisipasi masyarakat serta melestarikan keperca-

Karjuni Dt Maani, "Transparansi dan Akuntabilitas dalam Pelayanan Publik“, Jurnal Ilmiah Politik Kenegaraan,Vol.VIII No.1 Edisi Oktober 2009,Universitas Negeri Padang, hlm. 48.

3 H.Alwi Wahyudi, "Peran Strategis Birokrasi dalam menentukan Pelayanan Publik", Jurnal Konstitusi, Vol.1 No. 1 Edisi Juni 2011. Madiun: Fakultas Hukum Universitas Merdeka, hlm. 61. yaan masyarakat, terhadap aparatur birokrasi pemerintah.

Berkaitan dengan hal tersebut, Mita Widyastuti mengatakan, ${ }^{4}$ Selama ini ada anggapan dan kesan bahwa penyelenggaraan pelayanan merupakan monopoli pemerintah, masyarakat dilibatkan hanya pada saat pemerintah membutuhkan informasi dari masyarakat. Pendapat ini ditanggapi oleh Ruli Isa, ${ }^{5}$ yang menyatakan keluhan-keluhan masyarakat merupakan indikator pelayanan yang diberikan belum memenuhi harapan masyarakat, kemampuan sebuah organisasi mengenali kebutuhan masyarakat dengan memperhatikan aspirasi masyarakat dalam pelayanan, direalisasikan dalam kebijakan dan kegiatan, prosedur pelayanan dinilai dengan adanya saluran komunikasi atau cara untuk menampung keluhan-keluhan ma-syarakat.

Mengingat negara Indonesia adalah negara demokrasi, dimana kekuasaan berasal dari rakyat, rakyat yang menentukan dan memberi arah yang sesungguhnya menyelenggarakan kehidupan kenegaraan. Oleh karena itu, wajar jika Dewan Perwakilan Rakyat Daerah yang mewakili rakyat seharusnya mampu menyusun kebijakan dalam peraturan daerah tentang pelayanan publik yang sesuai dengan kebutuhan dan kepentingan masyarakat di daerahnya, baik di bidang pendidikan, kesehatan, transportasi, ekonomi, sosial budaya, dan bidang lainnya. Selain hal itu, di dalam masyarakat demokratis seringkali timbul persoalan bagaimana menyerap opini publik dan membangun suatu kebijakan tentang pelayanan publik yang mendapat dukungan publik. Pada saat ini, pelayanan publik menjadi isu yang sangat strategis dan sensitif dimana masyarakat semakin kritis terhadap kebijakan-kebijakan pemerintah yang berkaitan dengan pelayanan publik.

Masyarakat memandang pelayanan publik merupakan hak masyarakat sebagai sarana pemenuhan kebutuhan mendasar masyarakat un-

4 Mita Widyastuti, "Transparansi dalam Penyelenggaraan Pelayanan Publik", Jurnal LPPM Paradigma, Vol. 10 No. 2 Edisi Desember 2009, Bekasi: Universitas Islam 45, hlm. 157.

5 Ruli Isa, "Efektivitas Organisasi Kecamatan dalam Pelayanan Publik setelah menjadi perangkat Daerah", Jurnal Inovasi, Vol 6 No.4 Edisi Desember 2009, Universitas Negeri Gorontalo, hlm. 70. 
tuk mencapai kesejahteraan sosial. Oleh karena itu nilai-nilai yang ada di dalam masyarakat dan keterlibatan masyarakat dalam mengambil kebijakan merupakan faktor pendukung dalam mewujudkan kesejahterakan masyarakat.

Saat ini perhatian masyarakat tertuju pada sejauhmana kebijakan otonomi daerah dapat memberikan peningkatan kualitas dan efektivitas pelayanan publik. Hal ini disebabkan karena kebijakan pada masa orde baru yang bersifat sentralistik menimbulkan efek daerah tidak dapat mengambil kebijakan sesuai dengan kebutuhan dan kepentingan masyarakat sehingga kualitas pelayanan publik di daerah menjadi sangat rendah. Kondisi ini dapat membuat kualitas manajemen pemerintahan menjadi tidak produktif, tidak efektif dan tidak efesien sehingga muncul pula kualitas pelayanan publik yang tidak akuntabel, tidak transparan, ditambah lagi dengan kedudukan masyarakat masih diberlakukan sebagai objek, bukan sebagai subjek. Dari uraian di atas akan dibahas tentang Model Demokrasi dalam Peningkatan Kualitas Pelayanan Publik (Studi Otonomi Daerah dalam Meningkatkan Kesejahteraan Masyarakat Pasca Reformasi).

\section{Pembahasan}

\section{Efektivitas Pelayanan Publik}

Kriteria yang bisa digunakan untuk menilai atau mengukur suatu efektivitas menurut Steers: ${ }^{6}$ kemampuan menyesuaikan diri; produktivitas; kepuasan kerja; kemampuan berlaba; pencarian dan pemanfaatan sumber daya manusia. Berdasarkan dari lima kriteria tersebut, hanya 3 (tiga) kriteria saja yang digunakan untuk mengukur efektivitas birokrasi dalam memberikan pelayanan publik, yaitu: kemampuan menyesuaikan diri, produktivitas dan kepuasan kerja.

Kemampuan menyesuaikan diri berkaitan erat dengan kehidupan manusia di dalam memenuhi kebutuhan hidupnya harus bekerjasama dengan orang lain. Selanjutnya produktivitas merupakan rasio antara masukan dan keluaran. Pada organisasi publik produktivitas adalah se-

6 Richard M. Steers, 1985, Efektivitas Organisasi (Kaidah Prilaku), Jakarta: Erlangga, HIm. 206. jauhmana target yang ditetapkan oleh organisasi dapat direalisasikan dengan baik. Kepuasan kerja merupakan keadaan emosional yang menyenangkan atau tidak menyenangkan bagi seorang pekerja. Kepuasan kerja mencair-minkan sikap seseorang terhadap pekerjaannya.

Nuzsep Almigo mengatakan, ${ }^{7}$ ada hubungan positif yang signifikan antara kepuasan kerja dengan produktivitas kerja, menunjukkan bahwa semakin tinggi kepuasan kerja yang diterima karyawan semakin tinggi pula produktivitas kerjanya. Dengan pelayanan publik yang baik dan efisien, daerah kabupaten dan kota lebih dekat kepada rakyat yang harus dilayani, maka wajar jika daerah diberi wewenang yang besar dengan tujuan untuk meningkatkan pelayanan publik di daerahnya.

Alinea keempat Pembukaan UUD 1945 menyebutkan bahwa Negara melindungi segenap bangsa dan seluruh tumpah darah Indonesia, memajukan kesejahteraan umum, mencairdaskan kehidupan bangsa, dan ikut melaksanakan ketertiban dunia berdasarkan kemerdekaan, perdamaian abadi, dan keadilan sosial. Pernyataan tersebut memuat tentang tujuan negara Indonesia adalah untuk mencapai kesejahteraan masyarakat melalui penyelenggaraan kepentingan umum seperti menyelenggarakan pendidikan, memberikan pelayanan kesehatan kepada masyarakat, memberikan perlindungan hukum dan tidak diskriminatif dengan memberikan akses kepada rakyat untuk mendapatkan pelayanan dari pemerintah baik secara ekono$\mathrm{mi}$, politik, sosial dan budaya.

Negara Indonesia telah mengalami empat kali, perubahan UUD pertama Tahun 1999, perubahan kedua Tahun 2000, perubahan ketiga Tahun 2001 dan perubahan keempat Tahun 2002 telah memberi implikasi politik yang sangat luas dalam sistem ketatanegaraan Indonesia. Dari empat kali perubahan tersebut menimbulkan pengaruh signifikan dalam kehidupan politik Indonesia yang lebih demokratis se-

\footnotetext{
Nuzsep Almigo, "Hubungan antara Kepuasan Kerja dengan Produktivitas kerja Karyawan", Jurnal Psyche, Vol.1 No.1 Edisi Desember 2004, Palembang: Fakultas Psikologi Bina Darma, hlm. 58.
} 
suai dengan perkembangan dan perubahan masyarakat.

Sebagai negara yang demokratis pelayanan publik merupakan hak dasar setiap warga negara yang harus dipenuhi oleh negara, selain itu pelayanan publik merupakan bagian yang tidak terpisahkan dari kewajiban negara untuk mensejahterakan rakyatnya. Pasal 18 A UUD 1945 memuat prinsip-prinsip dasar yang memungkinkan terselenggaranya pelayanan masyarakat, hal tersebut diimplementasikan melalui Undang-Undang Nomor 25 Tahun 2009 tentang Pelayanan Publik.

Pengertian pelayanan publik menurut $\mathrm{Pa}$ sal 1 Undang-Undang Nomor 25 Tahun 2009 adalah kegiatan atau rangkaian kegiatan dalam rangka pemenuhan kebutuhan pelayanan sesuai dengan peraturan perundang-undangan bagi setiap warga negara dan penduduk atas barang, jasa dan/atau pelayanan administrasi yang disediakan oleh penyelenggara pelayanan publik.

Menurut Heryanto Monoarfa, ${ }^{8}$ pelayanan publik adalah pelayanan yang ditargetkan sebagai kepuasan bagi siapapun menerimanya. Dari pendapat dan pengertian pelayanan publik di atas dapat dipahami bahwa pelayanan publik adalah pemberian layanan atau melayani kebutuhan, kepentingan orang/masyarakat atau organisasi lain baik di pusat atau di daerah yang ditujukan untuk memberikan kepuasan kepada penerima pelayanan. Sesuai dengan aturan pokok dan tata cara yang ditentukan oleh undangundang. Segala bentuk jasa pelayanan, baik dalam bentuk barang publik maupun jasa publik yang menjadi tanggung jawab dilaksanakan oleh institusi pemerintah pusat dan daerah dalam rangka pemenuhan kebutuhan masyarakat.

Penyelenggara pelayanan publik adalah setiap institusi penyelenggara negara, korporasi, lembaga independen yang dibentuk berdasarkan undang-undang, untuk kegiatan pelayanan publik dan badan hukum lain yang dibentuk semata-mata untuk kegiatan pelayanan publik. Keputusan Menteri Pendayagunaan Apa-

\footnotetext{
8 Heryanto Monoarfa, "Efektivitas dan effisiensi Penyelenggaraan Pelayanan Publik: Suatu Tinjauan Kinerja Lembaga Pemerintahan“, Jurnal Pelangi Ilmu, Vol. 05 No. 01 Edisi 2012, Universitas Negeri Gorontalo, hlm. 1.
}

ratur Negara Nomor 63/KEPMEN/PAN/17/2003 tentang Pedoman Umum Penyelenggaraan Pelayanan Publik, antara lain memuat tentang hakekat pelayanan publik adalah pemberian pelayanan prima kepada masyarakat yang merupakan perwujudan kewajiban aparatur negara sebagai abdi masyarakat.

Keputusan Menpan Nomor 81 Tahun 1993 menegaskan bahwa dalam penyelenggaraan pelayanan publik harus mengandung unsur-unsur sebagai berikut. Pertama, hak dan kewajiban bagi pemerintah maupun penerima pelayanan umum harus jelas dan diketahui secara pasti oleh masing-masing pihak. Kedua, pengaturan setiap bentuk pelayanan umum harus disesuaikan dengan kondisi kebutuhan dan kemampuan masyarakat untuk membayar berdasarkan ketentuan peraturan perundang-undangan yang berlaku dengan tetap berpegang pada efisiensi dan efektivitas. Ketiga, mutu, proses dan hasil pelayanan umum harus diupayakan agar memberi keamanan, kenyamanan, kelancaran, dan kepastian hukum yang dapat dipertanggungjawabkan. Keempat, apabila pelayanan umum yang diselenggarakan oleh instansi pemerintah terpaksa harus mahal, maka instansi pemerintah yang bersangkutan berkewajiban memberi peluang kepada masyarakat untuk ikut menyelenggarakannya sesuai dengan peraturan perundang-undangan yang berlaku.

Pelayanan publik merupakan pola hubungan antara negara dengan masyarakat yang lebih mementingkan kepentingan masyarakat. Sebagai akibatnya, negara dituntut untuk memberikan pelayanan kepada masyarakat dengan lebih baik dan lebih demokratis, yang menekankan hak antara sesama warga negara.

\section{Tolak Ukur Kualitas Pelayanan Publik}

Undang-undang Pelayanan publik menegaskan bahwa standar pelayanan adalah tolok ukur yang dipergunakan sebagai pedoman penyelenggaraan pelayanan dan acuan penilaian kualitas pelayanan sebagai kewajiban dan janji penyelenggara kepada masyarakat dalam rangka pelayanan yang berkualitas, cepat mudah terjangkau dan terukur. Penyelenggara berkewajiban menyusun dan menetapkan standar pe- 
layanan dengan memperhatikan kemampuan penyelenggara, kebutuhan masyarakat dan kondisi lingkungan. Penyusun dan penetapkan standar pelayanan penyelenggara wajib mengikut sertakan masyarakat dan pihak terkait, pengikut sertaan masyarakat dan pihak terkait dilakukan dengan prinsip tidak diskriminatif, terkait langsung dengan jenis pelayanan memiliki kompetensi dan mengutamakan musyawarah serta memperhatikan keberagaman.

Erland Mou mengatakan, ${ }^{9}$ Dalam praktek pelayanan publik di berbagai daerah, seharusnya birokrasi selalu memberi perhatian terhadap permasalahan yang ditimbulkan dari pengaduan masyarakat. Keterlibatan birokrasi dalam pelayanan publik disamping menunjukkan manfaat dan keunggulan tertentu, sekaligus juga menunjukkan kelemahannya, yaitu terbatasnya sumber daya yang mumpuni serta ditambah dengan peraturan-peraturan yang membuat birokrat daerah bekerja dengan kaku. Birokrasi juga masih mendahulukan kepentingan tertentu tanpa memperhatikan konteks atau dimana birokrat bekerja atau berada dan mendahulukan orang atau suku sendiri merupakan tindakan yang biasa dilakukan dan diterapkan dalam konteks organisasi publik.

Menurut Peraturan Pemerintah Nomor 96 Tahun 2012 tentang Pelaksanaan Pelayanan Publik sebagaimana yang tertuang dalam Pasal 1 ayat 2 mencantumkan bahwa penyelenggara pelayanan publik yang selanjutnya disebut penyelenggara adalah setiap institusi penyelenggara negara, korporasi, lembaga independen yang dibentuk berdasarkan undang-undang untuk kegiatan pelayanan publik dan badan hukum lain yang dibentuk semata-mata untuk kegiatan pelayanan publik.

Menurut Peraturan Menteri Pendayagunaan Aparatur Negara dan Reformasi Birokrasi No. 36 Tahun 2012 bahwa rancangan standar pelayanan yang telah disusun oleh tim penyusun standar pelayanan, sebelum ditetapkan, terlebih dahulu dilakukan pembahasan, dalam penetapan standar pelayanan publik dinyatakan

Erland Mou, "Kualitas Pelayanan Publik di Daerah Sebuah Kajian Teoritis", Jurnal UNIERA, Vol. 2 No. 2 Edisi 2013, Halmahera: Universitas Halmahera, hlm. 92. kegiatan pengikutsertaan masyarakat dilakukan dalam forum pembahasan rancangan standar pelayanan (SP) dan sekurang-kurangnya dilakukan 2 (dua) kali, yaitu pada tahapan pembahasan rancangan standar pelayanan, dan setelah standar pelayanan selesai disusun dan ditetapkan, sekaligus dilanjutkan untuk mendiskusikan proses penyusunan maklumat pelayanan. Tujuan dari ikut sertanya masyarakat dalam forum pembahasan bersama adalah untuk menyelaraskan kemampuan penyelenggara pelayanan dengan kebutuhan/kepentingan masyarakat dan kondisi lingkungan guna mengefektifkan pelayanan yang berkualitas.

Pembahasan rancangan standar pelayanan ditujukan untuk membangun kesepakatan dan kompromi antara harapan masyarakat serta kesanggupan penyelenggara, terutama yang menyangkut pada kemampuan yang dimiliki, meliputi: dukungan pendanaan yang dialokasikan untuk penyelenggaraan pelayanan; pelaksana yang bertugas memberikan pelayanan dari segi kualitas maupun kuantitas; dan sarana prasarana dan fasilitas yang digunakan untuk menyelenggarakan pela-yanan.

Hasil pembahasan standar rancangan pelayanan harus dituangkan dalam berita acara penyusunan standar pelayanan dengan dilampiri daftar hadir peserta rapat sesuai dengan yang tertuang dalam Pasal 26 PP Nomor 96 Tahun 2012. Pelayanan yang diberikan kepada masyarakat selalu menuntut pelayanan publik yang berkualitas dari aparat birokrasi yang dilakukan secara transparan dan akuntabilitas. Asas atau pedoman penyelenggaraan pelayanan Publik diatur dalam Pasal 4 UU Nomor 25 Tahun 2009 terdiri dari:

a. Kepentingan umum adalah pemberian pelayanan tidak boleh mengutamakan kepentingan pribadi atau golongan.

b. Kepastian hukum adalah jaminan terwujudnya hak dan kewajiban dalam penyelenggaraan pelayanan.

c. Kesamaan hak adalah pemberian pelayanan tidak membedakan suku, ras, agama, golongan, gender dan status ekonomi.

d. Keseimbangan hak dan kewajiban adalah pemenuhan hak harus sebanding dengan kewajiban yang harus dilaksa- 
nakan, baik oleh pemberi maupun penerima pelayanan.

e. Keprofesionalan adalah pelaksana pelayanan harus memiliki kompetensi yang sesuai dengan bidang tugas.

f. Partisipatif adalah peningkatan peran serta masyarakat dalam penyelenggaraan pelayanan dengan memperhatikan aspirasi kebutuhan dan harapan ma-syarakat.

g. Persamaan perlakuan/tidak diskriminatif adalah setiap warga negara berhak memperoleh pelayanan yang adil.

h. Keterbukaan adalah setiap penerima pelayanan dapat dengan mudah mengakses dan memperoleh informasi mengenai pelayanan yang diinginkan.

i. Akuntabilitas adalah proses penyelenggaraan pelayanan harus dapat dipertanggungjawabkan sesuai dengan ketentuan peraturan perundang-undangan.

j. Fasilitas dan perlakuan khusus bagi kelompok rentan adalah pemberian kemudahan terhadap kelompok rentan sehingga tercipta keadilan dalam pelayanan.

k. Ketetapan waktu adalah penyelesaian setiap jenis pelayanan dilakukan tepat waktu sesuai dengan standar pelayanan.

l. Kecepatan, kemudahan dan keterjangkauan adalah setiap jenis pelayanan dilakukan secara cepat mudah dan terjangkau.

Asas penyelenggaraan pelayanan publik mencakup hal-hal yang wajib dipenuhi, sebagai pedoman pembentukan sebuah peraturan yang berkaitan dengan pelayanan publik dengan tujuan untuk mensejahterakan masyarakat. Dari unsur tersebut ibarat sebuah sistem secara fungsional saling melengkapi satu sama lain. Jika salah satu sistem tidak berjalan dengan baik menimbulkan ketidak seimbangan dalam pelaksanaan/penyelenggaraan pelayan publik yang dapat merugikan masyarakat.

Penyelenggara wajib mengikut sertakan masyarakat sebagai pihak terkait dalam menyusun standar pelayanan, hal ini didukung oleh Pendapat Samuel Atbar yang mengatakan, ${ }^{10}$ pe-

10 Samuel Atbar,"Pengaruh Perilaku Birokrasi terhadap Kualitas Layanan Publik pada Distrik Semangga", Jurnal Societas Fisip, No. 1 Jilid. 1 Edisi April 2012, Merauke/ rilaku birokrasi pemerintahan harus mengakomodasi dan menyalurkan kepentingan rakyat melalui berbagai kebijakan yang sesuai dengan kepentingan umum dan diarahkan membangun partisipasi masyarakat dalam mendukung dan mengelola kegiatan pemerintahan yaitu kegiatan pelayanan kepada masyarakat yang berpola pada hubungan keduanya.

Menurut Andi Wahyudi, ${ }^{11}$ urgensi komuniskasi dalam pelayanan publik memiliki peran yang sangat penting oleh karena proses penyelenggaraan pelayanan publik dengan kelengkapan yang meliputi ketersediaan sumber daya manusia, anggaran biaya, sarana dan prasarana serta metode pemberian pelayanan perlu dikemas dalam komunikasi yang baik antara penyedia dan pengguna layanan, tanpa komunikasi yang baik maka masyarakat tidak mengetahui upaya apa yang telah dilakukan oleh unit penyedia layanan publik.

Kualitas dalam penyelenggaraan sebuah pelayanan harus selalu dijaga dan ditingkatkan, mengingat masyarakat semakin cerdas menilai mana pelayanan yang baik dan mana yang buruk. Widodo mengutip pendapat Love Lock yang menyatakan, ${ }^{12}$ lima prinsip yang harus diperhatikan dalam pelayanan publik agar kualitas Pelayanan publik dapat dicapai. Pertama, tangible (terjemah) kemampuan fisik, peralatan, personil, dan komunikasi matrial, bentuk pelayanan fisik tersebut berupa kemampuan menggunakan dan memanfaatkan segala fasilitas alat dan perlengkapan di dalam memberikan pelayanan, sesuai dengan kemampuan penguasaan teknologi yang ditunjukkan secara fisik dan bentuk tampilan dari pemberi pelayanan sesuai dengan perilaku yang ditunjukkan. Kedua, reliabel (handal) yaitu kemampuan memberikan pelayanan sesuai dengan tingkat pengetahuan yang dimiliki, handal dan terampil menguasai bidang kerja yang diterapkan, sesuai pengala-

Papua: Universitas MUSAMUS, hlm 1-19.

11 Andi Wahyudi, "Urgensi Komunikasi dalam Menunjang Efektivitas Pelayanan Publik", Jurnal Borneo Administrator, Vol. 6 No. 3 Edisi 2010, Samarinda: PKP2A III LAN. hlm. 21-38.

12 Joko Widodo, 2001, Good Governance; Telaah dari Dimensi: Akuntabilitas dan Kontrol Birokrasi Pada Era Disentralisasi dan Otonomi di Daerah. Surabaya: Insan Cendekia, hlm 272. 
man kerja yang ditunjukkan dalam menggunakan teknologi kerja.

Ketiga, responsiveness (pertanggungjawaban) adalah rasa tanggungjawab terhadap mutu pelayanan dimana setiap pegawai dalam memberikan bentuk-bentuk pelayanan, mengutamakan aspek pelayanan yang sangat mempengaruhi perilaku orang yang mendapat pelayanan, sehingga diperlukan kemampuan daya tanggap dari pegawai untuk melayani masyarakat sesuai dengan tingkat penyerapan. Keempat, assurance (jaminan) yaitu pegawai yang memiliki pengetahuan, prilaku dan kemampuan sehingga orang yang menerima pelayanan merasa puas dan yakin bahwa segala bentuk urusan pelayanan yang dilakukan tuntas dan selesai sesuai dengan kecepatan, ketepatan, kemudahan, kelancaran. Kelima, emphaty (empati) yaitu mampu melayanani orang yang dilayani dengan penuh perhatian terhadap berbagai masalah yang membutuhkan pelayanan. Oleh karenanya, empati dalam suatu organisasi kerja menjadi sangat penting dalam memberikan suatu kualitas layanan sesuai prestasi kerja yang ditunjukkan oleh seorang pegawai.

Kualitas pelayanan berkaitan erat dengan kepuasan yang diterima oleh penerima pelayanan. Jika kinerja berada dibawah harapan, pelanggan akan tidak puas. Jika kinerja mele-bihi harapan, maka pelanggan akan merasa sangat puas atau senang. Menurut Jaelan Usman, ${ }^{13}$ solusi mengatasi persoalan kemunduran birokrasi dalam pelayanan publik meliputi: merubah persepsi dan paradigma birokrasi mengenai konsep pelayanan; adanya kebijakan publik yang lebih mengutamakan kepentingan publik dan pelayanan publik disbandingkan dengan kepentingan penguasa atau elit tertentu; unsur pemerintah privat dan masyarakat harus merupakan all together yang sinergi; adanya peraturan daerah yang mampu menjelaskan standar minimal pelayanan publik dan sanksi yang akan diberikan; adanya mekanisme pengawasan sosial yang jelas mengenai pelayanan publik antara birokrat

13 Jaelan Usman, “Manajemen Birokrasi Profesional dalam Meningkatkan Pelayanan Publik", Jurnal Otoritas Ilmu Pemerintahan, Vol. 1 No. 2 Edisi Oktober 2011, Makassar: Universitas Muhammadiyah, hlm. 109. dan masyarakat yang dilayani; adanya kepemimpinan yang kuat dalam melaksanakan komitmen pelayanan publik; adanya pembaharuan dibidang sistem administrasi publik; dan adanya upaya untuk memberdayakan masyarakat empowerment secara terus menerus dan demokratis.

Pendapat tersebut didukung pula oleh Sri Suwitri yang mengatakan, ${ }^{14}$ untuk tercapainya pelayanan prima dalam otonomi daerah, pemerintah daerah perlu memperhatikan dimensidimensi kualitas pelayanan, serta penerbitan peraturan daerah yang mampu menempatkan masyarakat sehingga dapat berpartisipasi sebagai informan, korektor, dan evaluator terhadap kualitas pelayanan publik. Pemerintah/birokrasi dalam memberi pelayanan kepada publik menempatkan kepentingan umum diatas kepentingan pribadi atau golongan, rela berkorban dan bekerja keras tanpa pamrih. Dengan semangat kejuangan itu seorang birokrat akan sanggup bertahan dari godaan untuk tidak berbuat yang bertentangan dengan nilai-nilai kebenaran, kebaikan keindahan, kebebasan, persamaan dan keadilan.

\section{Model Demokrasi dalam Pelayanan Publik}

Berbicara tentang pelayanan publik tidak akan terlepas dengan masyarakat dan demokrasi, sejak reformasi sistem pemerintahan yang semula yang menganut sentralisasi beralih ke model desentralisasi. Tujuan desentralisasi adalah peningkatan efisiensi dan efektifitas penyelenggaraan pemerintahan dan peningkatan partisipasi masyarakat dalam pemerintahan dan pembangunan.

Undang-Undang Nomor 32 Tahun 2004 tentang Pemerintahan Daerah menegaskan bahwa pemberian otonomi luas kepada daerah diarahkan untuk mempercepat terwujudnya kesejahteraan masyarakat melalui peningkatan pelayanan, pemberdayaan dan peran serta masyarakat. Peran serta masyarakat memberi makna bahwa penyelenggaraan desentralisasi dan oto-

14 Sri Suwitri, "Pelayanan publik dan kebijakan Otonomi Daerah di Indonesia", Jurnal Dialogue Jurnal Ilmu Administrasi dan Kebijakan Publik (JIAKP). Vol. 1 No. 1 Edisi Januari 2004, Semarang: Universitas Diponegoro, hlm. 76-85. 
nomi daerah memuat prinsip demokrasi yang menuntut partisipasi masyarakat dan kemandirian masyarakat di daerah.

UUD 1945 menyatakan bahwa Indonesia adalah negara demokrasi dimana kedaulatan adalah ditangan rakyat. Dalam pandangan faham demokrasi, hak menyampaikan pendapat dan aspirasi terhadap terselenggaranya pemerintahan yang baik adalah merupakan bagian dari pengejawantahan kedaulatan rakyat. Negara yang menerapkan asas demokrasi akan selalu melibatkan partisipasi masyarakat dalam penetapan dan perumusan kebijakan termasuk kebijakan penyelenggaraan pelayanan publik.

Rahendro jati mengatakan, ${ }^{15}$ dalam suatu negara yang menganut sistem perwakilan, partisipasi masyarakat tetap diperlukan karena selain untuk mewujudkan pemerintahan yang demokratis, juga diperlukan untuk mewujudkan masyarakat yang demokratis. Secara formal proses untuk mewujudkan produk undang-undang yang responsif melalui wujud partisipasi masyarakat sudah dilaksanakan karena beberapa peraturan Undang-undang yang mengatur mengenai tata cara pembentukan peraturan perundang-undangan sudah mengatur hal tersebut. Penerimaan aspirasi masyarakat secara substansi oleh para pembentuk Undang-undang untuk mewujudkan undang-undang yang responsif sangat tergantung pada sikap dan cara pandang pembentuk Undang-undang dengan berbagai kepentingan yang ada di dalamnya.

Partisipasi masyarakat merupakan dasar pelaksanaan demokrasi sesuai dengan cita-cita negara demokrasi yaitu mengedepankan kesejahteraan rakyat. Munir Fuady menyatakan, ${ }^{16}$ Hubungan antara partisipasi masyarakat dengan demokrasi memuat unsur-unsur sebagai berikut. Pertama, pemahaman yang jelas oleh warga negara tentang berbagai hal yang perlu diketahui; kedua, adanya wadah para warga negara dan masyarakat sipil (civil society) mendiskusi-

15 Rahendro jati, “Partisipasi Masyarakat dalam Proses Pembentukan Undang-undang yang Responsif" Jurnal Rechtsvinding Media Pembinaan Hukum Nasional, Vol. 1 No. 3 Edisi Desember 2012, Jakarta: Pusat Penelitian dan Pengembangan SHN BPHN, hlm 329.

16 Munir Fuady, 2009, Konsep Negara Demokrasi, Jakarta: PT Refika Aditama, hlm. 36. kan berbagai hal secara cerdas; ketiga, partisipasi yang efektif bagi para warga negara dalam proses pengambilan keputusan; keempat, kontrol akhir terhadap putusan-putusan politik tetap berada ditangan rakyat, dan kelima, kekuasaan publilk yang impersonal, yakni senantiasa dibatasi oleh hukum dengan pusat otoritas yang beraneka ragam.

Berdasarkan kelima unsur diatas dapat dikatakan bahwa landasan negara demokrasi adalah rakyat berhak untuk menentukan nasibnya, hak rakyat untuk menentukan nasibnya tersebut tidak hanya diberikan pada tingkat pemerintah pusat melainkan pada setiap tempat dari daerah kota sampai ke desa. Tiap-tiap kelompok atau golongan/rakyat memiliki akses untuk menyampaikan pendapatnya, dengan diberlakukannya otonomi daerah dan pemberian status kewenangan otonomi daerah kepada daerah yang tujuannya adalah untuk mendekatkan pelayanan kepada masyarakat sesuai dengan penyelenggaraan negara demokrasi. Selanjutnya Peraturan Pemerintah No. 68 Tahun 1999 tentang Tata Cara Pelaksanaan Peran Serta Masyarakat dalam Penyelenggaraan Negara, yang mengatur mengenai hak dan tanggung jawab serta kewajiban masyarakat dan penyelenggara negara.

Penyelenggara pelayanan publik yang disebut penyelenggara adalah setiap institusi penyelenggara negara, korporasi, lembaga independen yang dibentuk berdasarkan undang-undang untuk kegiatan pelayanan publik dan badan hukum lain dibentuk semata-mata untuk kegiatan pelayanan publik. Penyelenggara wajib mengikut sertakan masyarakat dalam penyelenggaraan pelayanan publik sebagai upaya membangun sistem penyelenggaraan pelayanan publik yang adil transparan dan akuntabel.

Endang Larasati menyatakan, ${ }^{17}$ bahwa reformasi kebijakan dalam penyelenggaraan pelayanan publik harus tetap berorientasi pada demokratisasi. Kebijakan penyelenggaraan pelayanan publik harus tumbuh dan berkembang se-

17 Endang Larasati, "Reformasi Pelayanan Publik (Public Services Reform) dan Partisipasi Publik”, Dialogue, Jurnal Ilmu Administrasi dan Kebijakan Publik, Vol.5 No.2 Edisi 2008, Semarang: Universitas Diponegoro, hlm. 264. 
suai dengan potensi lokal (local wisdom, local cultural) sehingga birokrasi pelayanan publik akan mengakar kuat. seiring dengan itu, demokratisasi yang terus berproses di tengah masyarakat harus menjadi orientasi birokrasi pelayanan publik yang akan dibentuk. Dengan demikian, birokrasi pelayanan publik berjalan seiring dengan benih demokrasi didaerah, sesuai dengan local culture dan local wisdom dalam kehidupan masyarakat suatu bangsa.

Endang Larasati berpendapat ${ }^{18}$ bahwa pentingnya struktur pengaturan pelayanan publik untuk dicermati dan dibenahi lebih detail kasus demi kasus dalam berbagai sektor pelayanan, sementara pengaturan pelayanan publik masih dirasakan gamang hanya sekedar memenuhi tuntutan tugas dan peraturan. Pengaturan tentang tertib pelayanan publik, masih tersebar-sebar dalam berbagai peraturan yang terfragmentasi secara sektoral dan tak menggambarkan koherensi yang logis, apalagi masingmasing bersandar pada standar yang berbedabeda, telah menjadikan pelayanan publik yang ada di Indonesia saat ini tetap berada pada suatu kondisi yang unmanageable. Pendapat Larasati menggambarkan pentingnya peraturanperaturan hukum yang mengatur pelayanan publik antara satu dengan yang lain saling mendukung untuk mewujudkan suatu kepastian hukum/tidak ambigu yang dijadikan sebagai pedoman yang dapat memberi perlindungan hukum kepada masyarakat sebagai penerima pelayanan publik.

Penerima pelayanan selain mempunyai hak dan kewajiban, juga mendapat perlindungan hukum dari peraturan-peraturan yang berkaitan dengan pelayanan publik. Istiana Heriana, ${ }^{19}$ mengatakan Perlindungan hukum bagi masyarakat dalam memperoleh pelayanan publik oleh pemerintah melalui perlindungan hukum

18 Endang Larasati, "Pelayanan Publik dan Demokrasi dalam kehidupan berbangsa dan bernegara", Dialogue Jurnal Ilmu Administrasi dan Kebijakan Publik, Vol. 5 No. 1 Edisi 2008, Semarang: Universitas Diponegoro, hlm.104.

19 Istiana Heriana, “Perlindungan Hukum Terhadap Hak Masyarakat dalam memperoleh pelayanan Publik oleh Pemerintah Daerah", Jurnal Ilmu-ilmu Social Socioscientia, Vol. 5 No. 1 Edisi Februari 2013, Kalimantan: Uniska Muhammad Arsyad Al-Banjary, hlm. 49. preventif maupun perlindungan hukum refresif memiliki makna memberikan perlindungan kepada masyarakat agar terlindungi dengan perangkat-perangkat hukum.

Perlindungan hukum bagi masyarakat dilakukan agar hak-hak maupun kewajiban masyarakat dalam memperoleh pelayanan terpenuhi diantaranya hak atas kebenaran isi standar pelayanan; hak mendapat tanggapan terhadap pengaduan yang diajukan; hak mendapat advokasi, perlindungan, dan/atau pemenuhan pelayanan; hak atas memberitahukan penyelenggara untuk memperbaiki pelayanan apabila pelayanan yang diberikan tidak sesuai dengan standar pelayanan; hak mengadukan pelaksana yang mengadukan penyimpangan standar pelayanan dan/atau tidak memperbaiki pelayanan kepada penyelenggara dan ombudsman; dan hak untuk mendapat pelayanan yang berkualitas sesuai dengan asas dan tujuan pelayanan.

Terbitnya Undang-undang Nomor 25 Tahun 2009 tentang Pelayanan publik adalah dalam rangka pemenuhan kebutuhan pelayanan sesuai dengan perundang-undangan, bagi setiap warga negara dan penduduk atas barang, jasa atau pelayanan administratif yang diselenggarakan oleh penyelenggara pelayanan publik sebagaimana dinyatakan dalam Pasal 1 ayat 1 pengaturan ini, Dapat dilihat dari teori yang berkaitan erat dengan masyarakat yaitu melihat bagaimana bekerjanya hukum di dalam masyarakat seperti yang dikemukakan oleh William J. Chambliss and Robert B. Seidman, yang melihat bekerjanya hukum di dalam masyarakat didasarkan pada dua konsep yang berbeda yaitu konsep tentang ramalan-ramalan mengenai akibat-akibat (prediction of consequences) yang dikemukakan oleh Lundberg dan Lansing tahun 1973 dan konsep Hans Kelsen tentang aspek rangkap dari suatu peraturan hukum. ${ }^{20}$

Teori bekerjanya hukum di dalam masyarakat jika diterapkan pada Model demokrasi dalam Peningkatan pelayanan publik, menggambarkan 4 (empat) unsur yang saling berkaitan

20 William J. Chambliss and Robert B. Seidman dalam Ronny Hanitijo Soemitro,1989, Perspektif Sosial dalam Pemahaman Masalah-Masalah Hukum, Semarang: CV Agung, hlm. 23. 
sangat erat. ${ }^{21}$ Pertama, setiap peraturan hukum menunjukkan tentang bagaimana pemegang peranan (role occupant) harus bertindak; kedua, bagaimana pemegang peranan itu akan bertindak sebagai respons terhadap peraturan hukum merupakan fungsi peraturan hukum yang ditujukan pada sanksi-sanksinya, aktivitas dari lembaga-lembaga pelaksana serta keseluruhan kompleks kekuatan sosial, politik dan lain-lainnya mengenai dirinya; ketiga, bagaimana lembaga-lembaga pelaksana itu akan bertindak sebagai respon terhadap peraturan hukum merupakan fungsi peraturan-peraturan hukum yang ditujukan kepada mereka sanksi-sanksinya, keseluruhan kompleks kekuatan-kekuatan sosial, politik dan lain-lainnya mengenai diri mereka serta umpan-umpan balik yang datang dari para pemegang peranan; dan keempat, bagaimana para pembuat undang-undang itu akan bertindak merupakan fungsi peraturan-peraturan yang mengatur tingkah laku mereka, sanksisanksinya, keseluruhan kompleks kekuatan-kekuatan sosial, politik, ideologis dan lain-lainnya yang mengenai diri mereka serta umpan-umpan balik yang datang dari pemegang peranan serta birokrasi. Keempat unsur diatas dapat diketahui setiap anggota masyarakat sebagai pemegang peranan ditentukan tingkah lakunya oleh pola peranan yang diharapkan baik oleh normanorma hukum maupun kekuatan-kekuatan di luar hukum.

Teori bekerjanya hukum di dalam masyarakat tersebut, mencerminkan penerapan sebuah demokrasi dimana masyarakat sebagai pemegang peran (role occupant)merupakan faktor penting dalam pembentukan peraturan perundang-undangan. Selain itu unsur kekuatan sosial yang ada dalam masyarakat menekan lembaga pembuat hukum berupa tuntutan-tuntutan untuk memecahkan masalah yang ada di dalam masyarakat. Akhirnya lembaga penegak hukum bekerja membuat peraturan yang bertujuan mengatur masyarakat agar menjadi lebih baik.

Teori bekerjanya hukum di dalam masyarakat tersebut jika dihubungkan dengan model demokrasi dalam peningkatan kualitas pelayan-

21 Ibid, hlm. 27. an publik bahwa lembaga pembuat peraturan (law making institution) dalam membentuk dan menyusun peraturan atau kebijakan bersamasama masyarakat dalam bentuk partisipasi sehingga dapat terjadinya hubungan komunikasi antara pembuat peraturan dengan masyarakat (stakeholders). Lembaga penerap sanksi yang terdiri dari aparat birokrasi juga dipengaruhi faktor sosial-personal selaku pengontrol terhadap pelayanan publik yang berkualitas. Jika ternyata ada indikasi bahwa pelayanan publik yang dilaksanakan oleh aparat birokrasi memiliki kualitas rendah, hal ini disebabkan karena aparat birokrasi tidak melaksanakan tugasnya melayani masyarakat secara optimal. Selanjutnya pemegang peran masyarakat (stakeholders) dalam sistem demokrasi bertindak sebagai subjek yaitu dapat memberikan respon sebagai umpan balik baik kepada pembuat peraturan (law making institution) dan kepada penerap sanksi.

Berdasarkan uraian diatas maka penerapan model demokrasi dalam meningkatkan kualitas pelayanan publik yang dikaitkan dengan pengertian awal demokrasi yaitu pemerintahan dari rakyat oleh rakyat dan untuk rakyat. Pemerintahan dari rakyat adalah pemerintahan negara itu mendapat mandat dari rakyat untuk menyelenggarakan pemerintahan, pemerintahan oleh rakyat yaitu pemerintahan negara itu dijalankan oleh rakyat, dan pemerintahan untuk rakyat maksudnya pemerintahan itu menghasilkan dan menjalankan kebijakan-kebijakan yang diarahkan untuk kepentingan dan kesejahteraan rakyat.

Penerapan model demokrasi mengandung arti bahwa penyelenggaraan desentralisasi dan otonomi daerah berkaitan dengan pelayanan publik menuntut adanya partisipasi dan kemandirian masyarakat daerah untuk ikut serta mengambil kebijakan.

Ada dua hal yang menjadi point pada Model demokrasi dalam peningkatan kualitas pelayanan publik. Pertama, lembaga pembuat peraturan selaku penyelenggara pemberi pelayanan (pemerintah) harus bersikap terbuka, transparansi, tidak diskriminatif dalam menyusun dan menetapkan standar pelayanan dan 
wajib mengikut sertakan masyarakat dan pihak terkait agar kebijakan publik sesuai dengan kebutuhan dan kepentingan masyarakat; dan kedua, pemegang peran (stakeholders) selaku penerima layanan memiliki posisi setara dengan lembaga pembuat peraturan, maksudnya masyarakat memiliki kedudukan selain sebagai objek juga sebagai subyek. Disatu pihak stakeholders sebagai obyek melaksanakan peraturan yang dibuat oleh pemerintah. Selain hal itu, stakeholders juga sebagai subjek yang memiliki hak untuk ikut berpartisipasi dalam mengambil kebijakan seperti yang dinyatakan dalam Pasal 96 UU Nomor 12 Tahun 2011 yang mengatur bahwa masyarakat berhak memberikan masukan secara lisan dan/atau tertulis dalam pembentukan peraturan perundang-undangan". Masukan secara lisan dan tertulis dapat dilakukan dengan: rapat dengar pendapat umum; kunjungan kerja; sosialisasi; dan seminar lokakarya dan diskusi.

Selanjutnya Pasal 40 Peraturan Pemerintah Nomor 96 Tahun 2012 tentang pelaksanaan Undang-Undang Nomor 25 Tahun 2009 tentang pelayanan publik menegaskan penyelenggara wajib mengikutsertakan masyarakat dalam penyelenggaraan pelayanan publik sebagai upaya membangun sistem penyelenggaraan pelayanan publik yang adil, transparan dan akuntabel. Pengikut sertaan masyarakat dalam pelayanan publik sebagaimana ditentukan dalam Pasal 41 mencakup keseluruhan proses penyelenggaraan pelayanan publik yang meliputi: penyusunan kebijakan pelayanan publik; penyusunan standar pelayanan; pengawasan dan evaluasi penyelenggaraan pelayanan publik; dan pemberian penghargaan. Keikutsertaan masyarakat dalam pelayanan publik disampaikan dalam bentuk masukan, tanggapan, laporan atau pengaduan kepada penyelenggara dan atasan langsung penyelenggara atau pihak terkait sesuai dengan ketentuan peraturan perundang-undangan atau media massa. Penyelenggara wajib memberikan informasi kepada masyarakat mengenai tindak lanjut penyelesaian masukan, tanggapan dan laporan atau pengaduan. Selain itu, keikutsertaan masyarakat dalam pelayanan publik mengacu pada prinsip: terkait langsung pada masyarakat pengguna pelayanan; memilki kompetensi sesuai dengan jenis pelayanan yang bersangkutan; mengedepankan musyawarah, mufakat dan keberagaman masyarakat. Keikutsertaan keterlibatan masyarakat dalam proses penyelenggaraan pelayanan publik merupakan faktor utama dan penting yang memberi pengaruh dalam membuat kebijakan yang sesuai dengan kebutuhan dan kepentingan masyarakat.

Lembaga pelaksana/aparat birokrasi menerima dan menindak lanjuti respons dari masyarakat, baik berupa masukan maupun pengaduan selain itu aparat birokrasi harus selalu meningkatkan kemampuan dan kinerja guna meningkatkan kualitas pelayanan kepada masyarakat. Kontrol masyarakat tehadap penyelenggara pelayanan publik akan memberikan dampak positif terhadap pemenuhan kebutuhan dan kepentingan masyarakat. Ketiga unsur tersebut saling berkaitan erat merupakan sebuah sistem yang saling bersinergi. Jika salah satu tidak berjalan dengan baik akan menimbulkan ketidakseimbangan yang dapat memberi pengaruh pada peningkatan kualitas pelayanan publik.

\section{Penutup}

Simpulan

Ada beberapa simpulan yang bisa dipetik dari pembahasan terhadap permasalahan yang telah diuraikan, terutama berkaitan dengan kendala dalam penerapan model demokrasi dalam peningkatan kualitas pelayanan publik. Pertama, pasca reformasi tindakan pemerintah daerah/penyelenggara pelayanan publik bersikap tertutup, sikap penyelenggara yang seharusnya pada posisi melayani masyarakat/melayani apa yang dibutuhkan masyarakat. Saat ini yang terjadi justru sebaliknnya, penyelenggara dilayani masyarakat, sehingga timbul asumsi bahwa institusi pelayanan identik dengan pelayanan yang tidak responsif, berbelit-belit, lamban, biaya tinggi, keadaan ini adalah akibat dari pengaruh sistem sentralistik yang bersikap top down. Keadaan ini mengakibatkan tidak terjalinnya komunikasi yang baik antara penyelenggara dan masyarakat yang berkepentingan sehingga kebijakan pelayanan publik tidak se- 
suai dengan kebutuhan masyarakat. Keadaan ini menimbulkan rendahnya kualitas pelayanan publik.

Kedua, menetapkan standar pelayanan publik, tidak sensitif terhadap kebutuhan dan kepentingan masyarakat, sehingga dalam penerapan pelayanan menimbulkan kesenjangan yang tidak sesuai dengan kebutuhan dan kepentingan masyarakat, faktor evaluasi sangat penting untuk mengetahui penyebab timbulnya kesenjangan. Dalam Pasal 20 masyarakat dan penyelenggara pelayanan publik melakukan diskusi, musyawarah, dan menerima masukan dari masyarakat dapat dijadikan bahan untuk perbaikan dalam upaya meningkatkan kualitas pelayanan publik agar sesuai dengan harapan masyarakat.

Ketiga, kemampuan birokrasi yaitu petugas yang menyediakan pelayanan publik bagi masyarakat, masih belum bersikap netral karena masih dipengaruhi oleh kepentingan-kepentingan politik dan ekonomi tertentu (kepentingan daerah). Keempat, kontrol masyarakat dan pengaduan masyarakat belum berjalan optimal karena masyarakat belum banyak mengetahui bahwa masyarakat mempunyai hak untuk melakukan pengawasan dan pengaduan dengan menyampaikan keluhan-keluhan apabila penyelenggara melakukan penyimpangan dari muatan /substansi standar pelayanan.

\section{Saran}

Sebagai saran, model demokrasi dalam peningkatan kualitas pelayanan publik harus memuat beberapa indikator. Pertama, sikap keterbukaan dan transparan dari Lembaga yang membentuk peraturan daerah tentang pelayanan publik dalam menerima masukan-masukan dari masyarakat/kelompok yang berkepentingan sehingga dapat mengakomodir kebutuhan dan kepentingan masyarakat, yang dimulai sejak membuat naskah akademik sampai menyusun draft, sampai evaluasi. Kedua, masyarakat/ stakeholders ikut menyusun dan menetapkan standar pelayanan mulai dari menyusun draft awal sampai dengan evaluasi, keputusan diambil dengan mengutamakan musyawarah untuk mencapai mufakat.
Ketiga, sanksi yang tegas bagi penyelenggara pelayanan publik jika memberikan pelayanan yang tidak sesuai dengan standar pelayanan dan melanggar larangan yang telah diatur dalam perundang-undangan, sanksi diberikan dalam benyuk teguran tertulis, penurunan pangkat lebih rendah selama satu tahun sampai dengan pembebasan dari jabatan dan pemberhentian dengan tidak dengan hormat, selanjutnya untuk perbuatan melawan hukum yang dilakukan oleh penyelenggara dalam bentuk tindak pidana yang dijatuhkan sanksi berdasarkan keputusan pengadilan. Keempat, masyarakat berhak mengontrol dan menyampaikan pengaduan atau keluhan jika pelayanan yang diterima tidak sesuai dengan harapan yang telah dijanjikan oleh pemerintah/pemberi pelayanan.

\section{Daftar Pustaka}

Almigo, Nuzsep. "Hubungan antara Kepuasan Kerja dengan Produktivitas kerja Karyawan”. Jurnal Psyche. Vol. 1 No. 1 Edisi Desember 2004. Palembang: Fakultas Psikologi Bina Darma.

Atbar, Samuel. "Pengaruh Prilaku Birokrasi terhadap kualitas Layanan Publik pada Distrik Semangga". Jurnal Societas Fisip. No. 1 Jilid. 1 Edisi April 2012. Merauke: Universitas MUSAMUS;

Fuady, Munir. 2009. Konsep Negara Demokrasi. Jakarta: PT Refika Aditama;

Heriana, Istiana. "Perlindungan Hukum Terhadap Hak Masyarakat dalam memperoleh pelayanan Publik oleh Pemerintah Daerah". Jurnal Ilmu-ilmu sosial Socioscientia. Vol. 5 No. 1 Edisi Februari 2013. Kalimantan: Uniska Muhammad Arsyad Al-Banjary;

Isa, Ruli. "Efektivitas Organisasi Kecamatan dalam Pelayanan Publik setelah menjadi perangkat Daerah". Jurnal Inovasi. Vol.6 No.4 Edisi Desember 2009. Universitas Negeri Gorontalo;

Jati, Rahendro. "Partisipasi Masyarakat Dalam Proses Pembentukan Undang-undang yang Responsif". Jurnal Rechtsvinding Media Pembinaan Hukum Nasional. Vol. 1 No. 3 Edisi Desember 2012. Jakarta: Pusat Penelitian dan Pengembangan SHN Badan Pembinaan Hukum Nasional; 
Larasati, Endang. "Pelayanan Publik dan Demokrasi dalam kehidupan berbangsa dan bernegara". Dialogue Jurnal Ilmu Administrasi dan Kebijakan Publik. Vol. 5 No. 1 Edisi 2008. Semarang: Universitas Diponegoro;

"Reformasi Pelayanan Publik (Public Services Reform) dan Partisipasi Publik Dialogue." Jurnal Ilmu Administrasi dan Kebijakan Publik. Vol. 5 No. 2 Edisi 2008. Semarang: Universitas Diponegoro;

Maani, Karjuni Dt. "Transparansi dan Akuntabilitas dalam Pelayanan Publik". Jurnal IImiah Politik Kenegaraan. Vol. VIII No. 1 Edisi Oktober 2009. Padang: Universitas Negeri Padang;

Malau, Hasbullah. "Menyoal Pelayanan Publik yang Berkualitas di Era Otonomi Daerah". Jurnal Ilmiah Politik Kenegaraan. Vol. VIII No. 1 Edisi Oktober 2009. Universitas Negeri Padang;

Monoarfa, Heryanto. "Efektivitas dan effisiensi Penyelenggaraan Pelayanan Publik: suatu tinjauan Kinerja Lembaga Pemerintahan". Jurnal Pelangi Ilmu. Vol. 05 No. 01 Edisi 2012. Gorongtalo: Universitas Negeri Gorontalo;

Mou, Erland. "Kualitas Pelayanan Publik di Daerah Sebuah Kajian Teoritis", Jurnal UNIERA. Vol. 2 No. 2 Edisi 2013. Universitas Halmahera.

Soemitro, Ronny, Hanitijo. 1989. Perspektif Sosial dalam Pemahaman Masalah-Masalah Hukum. Semarang: CV. Agung;

Steers, M Richard. 1985. Efektivitas Organisasi (Kaidah Prilaku). Jakarta: Erlangga;

Suwitri, Sri. "Pelayanan publik dan kebijakan Otonomi Daerah di Indonesia". Jurnal Dialogue Jurnal Ilmu Administrasi dan Kebijakan Publik (JIAKP). Vol. 1 No. 1 Edisi Januari 2004. Semarang: Universitas Diponegoro;

Usman, Jaelan. "Manajemen Birokrasi Profesional dalam Meningkatkan Pelayanan Publik". Jurnal Otoritas Ilmu Pemerintahan. Vol. 1 No. 2 Edisi Oktober 2011. Makasar: Universitas Muhammadiyah;

Wahyudi, Andi. "Urgensi Komunikasi dalam Menunjang Efektivitas Pelayanan Publik". Jurnal Borneo Administrator. Vol. 6 No. 3 Edisi 2010. Samarinda: PKP2A III LAN;

Wahyudi, H.Alwi. "Peran Strategis Birokrasi dalam menentukan Pelayanan Publik". Jurnal Konstitusi. Vol. 1 Nomor. 1 Edisi Juni
2011. Madiun: Fakultas Hukum Universitas Merdeka;

Widodo, Joko. 2001. Good Governance; Telaah dari Dimensi: Akuntabilitas dan Kontrol Birokrasi Pada Era Disentralisasi dan Otonomi di Daerah. Surabaya: Insan Cendekia;

Widyastuti, Mita. "Transparansi dalam Penyelenggaraan Pelayanan Publik". Jurnal LPPM Paradigma. Vol. 10 No. 2 Edisi Desember 2009. Bekasi: Universitas Islam. 